\title{
Failure Analysis of Apennine Masonry Churches Severely Damaged during the 2016 Central Italy Seismic Sequence
}

\author{
Francesco Clementi
}

Citation: Clementi, F. Failure

Analysis of Apennine Masonry

Churches Severely Damaged during the 2016 Central Italy Seismic Sequence. Buildings 2021, 11, 58. https://doi.org/10.3390/buildings 11020058

Academic Editors: Maria Polese and Marco Gaetani d'Aragona

Received: 7 January 2021

Accepted: 4 February 2021

Published: 8 February 202

Publisher's Note: MDPI stays neutral with regard to jurisdictional claims in published maps and institutional affiliations.

Copyright: (C) 2021 by the author. Licensee MDPI, Basel, Switzerland. This article is an open access article distributed under the terms and conditions of the Creative Commons Attribution (CC BY) license (https:// creativecommons.org/licenses/by/ $4.0 /)$
Department of Civil and Building Engineering, and Architecture, Polytechnic University of Marche, 60131 Ancona, Italy; francesco.clementi@univpm.it; Tel.: +39-071-220-4569

\begin{abstract}
This paper presents a detailed study of the damages and collapses suffered by various masonry churches in the aftermath of the seismic sequence of Central Italy in 2016. The damages will first be analyzed and then compared with the numerical data obtained through 3D simulations with eigenfrequency and then nonlinear static analyses (i.e., pushover). The main purposes of this study are: (i) to create an adequately consistent sensitivity study on several definite case studies to obtain an insight into the role played by geometry-which is always unique when referred to churches-and by irregularities; (ii) validate or address the applicability limits of the more widespread nonlinear approach, widely recommended by the Italian Technical Regulations. Pushover analyses are conducted assuming that the masonry behaves as a nonlinear material with different tensile and compressive strengths. The consistent number of case studies investigated will show how conventional static approaches can identify, albeit in a qualitative way, the most critical macro-elements that usually trigger both global and local collapses, underlining once again how the phenomena are affected by the geometry of stones and bricks, the texture of the wall face, and irregularities in the plan and elevation and in addition to hypotheses made on the continuity between orthogonal walls.
\end{abstract}

Keywords: collapses; masonry churches; Central Italy earthquake; damage; nonlinear static analysis

\section{Introduction}

The Architectural Heritage (AH) of European countries, which includes iconic buildings like churches, historical palaces, towers, monuments, as well as historical bridges, wall, small villages, etc., is a pillar of the societal identity and among the most strategic world's economic assets, making its preservation a commitment towards future generations. Many countries of the Mediterranean area are characterized by a high level of seismicity, which constantly puts at risk AH structures. This is especially true in Italy, which hosts the largest number of towers, churches, fortresses, etc., in the world, and where some earthquakes, which occurred in the last few decades (Umbria-Marche 1997-1998, Abruzzo 2009, Emilia-Romagna 2012, Central Italy 2016), dramatically damaged several unique pieces of the $\mathrm{AH}$. In particular, the Central Italy seismic sequence leads to a total of 299 fatalities, 386 injured and about 4800 homeless [1].

The effects of the earthquake are such as to produce considerable damage, especially in the $\mathrm{AH}$, with catastrophic loss of income from cultural tourism in some areas, with both social and economic inconveniences for local communities. Moreover, the loss of the $\mathrm{AH}$ can lead to the dispersion of collective memory and European identity, and the accessibility to AH usually leads to a significant improvement of the economics, enhancing social uniqueness. For these reasons, ensuring historical buildings to be safe and functional, along with infrastructures, will certainly enhance their usability and therefore the livability of cities.

Simple and efficient tools are the basis for a correct assessment of seismic safety. Structural Health Monitoring (SHM) and non-destructive (ND) testing play a major role, providing information on the building condition and existing damage, and allowing us to 
define adequate remedial measures. Numerical tools, however, can be used to complete or partially replace them, requiring expert judgment in most cases.

$\mathrm{AH}^{\prime}$ 's structural assessment is one of the most complex part of structural engineering and is an active research area [2], exhibiting the constituting materials significant variations in properties and internal structure, which affect local and global behaviors. These aspects are reflected in the conservativeness of the reference values of the resistances that the manuals, guidelines, or codes [3-6] impose for the existing structures. The different tensile and compressive strengths, in addition to the strong nonlinear behavior of the masonry, require the use of challenging modeling techniques, some of them requiring the use of anisotropic constitutive laws.

The mechanical behavior of masonry shows that the nonlinear phase is predominant and characterized mainly by crack opening, splitting the structures into macro-blocks. The decrease in the masonry's strength in the inelastic phase is generally considered with an elastic plastic damage constitutive law [7-11]. Nonetheless, numerical analysis itself is still a challenging issue, especially working with high-dimensional problems. [12-14].

There are two distinct methods that can be established [15-17]. The continuous approach discretizes the masonry's walls by means of Finite Element Method (FEM), using beam, shell and solids elements [18,19]. The discrete approach, alternative to the first, considers the masonry as an assembly of blocks that can impact, and slide between them [20-23].

In this paper, referring to FEM, it was possible to recognize the mechanical performance of six different churches, supplying helpful data for conservation, repair and strengthening interventions of AH [24-26]. Above all, the FEM is the most powerful and frequently used modelling approach for structural seismic response, and for this reason the results obtained in this paper will be of greater use also for practitioners and not just for academics.

The paper is scheduled as follows. In Section 2, both the historical developments and the main features of the selected case studies are reported. In Section 3, after a brief illustration of the modelling strategy, modal analyses are reported and compared with response spectra of the three main shocks of Central Italy seismic sequence of 2016 [27,28], in order to have a first inside on the main structural portions that are most involved during a seism. In Section 4, a comparison between the real and the numerical damages are reported and discussed. The paper ends with some conclusions (Section 5).

\section{Apennine Churches}

The churches that characterize the Apennine area of central Italy have a very different plano-volumetric configuration from those sited in the inhabited areas heavily damaged by the earthquakes of L'Aquila 2009 and Emilia-Romagna 2012. This is mainly linked to the peculiar orographic conformation of the territory that paved the way to small, sparsely populated villages, between hills and narrow valleys, characterized by a main urban center and many hamlets, mostly scattered on the peaks of the surrounding hills and mountains. For this reason, it was impossible to build monumental churches that belonged only to the main urban center, thus favoring the development of many smaller churches both in the main villages and in the hamlets. An example is the Municipality of Castelsantangelo sul Nera, characterized by a total of 246 inhabitants scattered in eight hamlets, and which hit the headlines for the enormous destruction suffered by the 2016 earthquake.

The strong propensity of the area to earthquakes has led to design churches and other buildings of the cultural heritage with very strict rules, leaving no impetus towards the construction of majestic structures. Specifically, the churches were built starting from a small medieval core, with minor expansions made in different centuries, most of them in the shape of side chapels and altars whose design was encouraged after the Catholic Counter-Reformation, as well as adjustments made after strong earthquakes. An example is the Collegiate Church of Santa Maria in Visso [29], characterized by a beautiful but equally rare bell tower that stands out from the church. In fact, the churches in the Apennine 
area are almost entirely built with a single nave, with not very high walls, and with small annexes surrounding them where the sacristies or ancillary rooms are concentrated. The facades are often adorned with a rose window and a triangular tympanum. In place of the bell tower it is common to find a bell-gable along the walls of the nave and supporting a small bell. The walls of the nave are embellished with small windows, with roofs with wooden trusses. The presence of apses is rare.

Finally, it is important to stress the fact that in the main cities at the base of the Apennine areas, the classic churches typologies widely analyzed in literature are clearly visible, but which will represent the subject of future works.

In the following paragraph, a concise description of the main historical and geometrical features of the analyzed "Apennine Churches" is provided. Furthermore, in Figure 1 is possible to observe the churches' locations inside the Marche region (Central Italy) and respect to the epicenters of the seismic sequence of 2016.

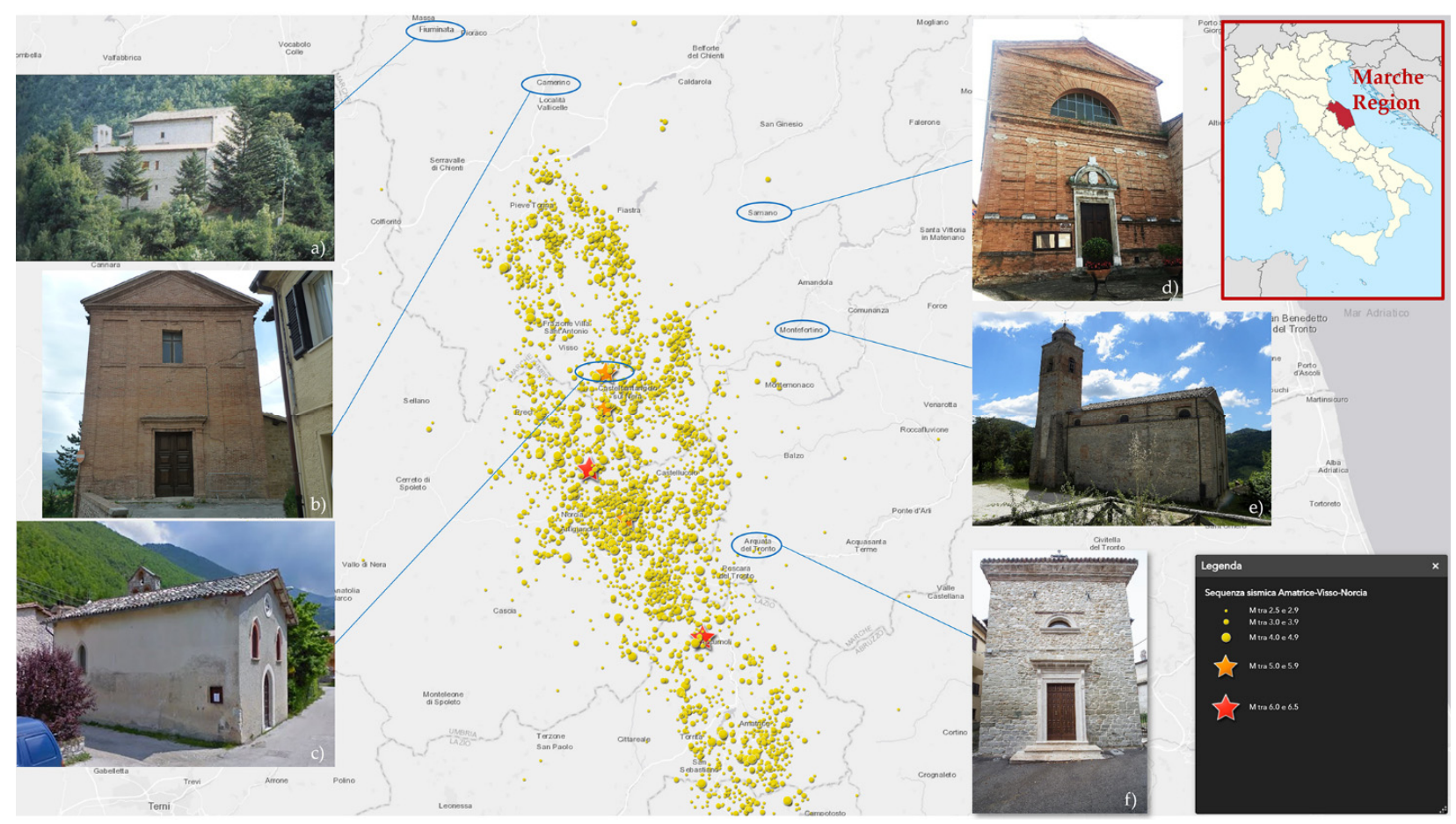

Figure 1. Churches' locations respect to the Epicenters of Central Italy seismic sequence of 2016: Madonna of Valcora Sanctuary in Fiuminata (a), Sant'Anna Church in Camerino (b), Sant'Antonio Church in Ussita (c), San Francesco Church in Sarnano (d), San Francesco Church in Montefortino (e), Santissimo Crocifisso in Arquata del Tronto (f).

\subsection{San Francesco Church in Montefortino (Marche Region, Fermo Province)}

San Francesco Church was built in the 15th century on remains of ancient Santa Maria of Girone church. The church is Romanesque-Gothic's style, with a unique nave of $20.36 \mathrm{~m}$ length and $10.89 \mathrm{~m}$ width, and a maximum height of $15.53 \mathrm{~m}$. The apse has $9.36 \mathrm{~m}$ length and $7.1 \mathrm{~m}$ width dimensions, covered by a barrel vault. On the north façade, there is a belfry with a height of $24.24 \mathrm{~m}$. Different retrofitting interventions occurred after the UmbriaMarche earthquake happened in September 1997, since the church highlighted serious damages on the façade, on the apse's vault and on the bell cell. In general, the church's walls are realized by disordered rubble stone masonry, while the roof is made by wooden beams.

During the seismic sequence of 2016, major cracks appeared on the barrel vault of the apse, decorated with rich stuccos (v. Figure 2a). The presence of a crack, between the bell-tower and the apse, suggest the possibility of the activation of a bell tower rotation. Different minor cracks developed on the connections between the façade and nave's walls, 
between the north wall and the bell-tower, on the middle of façade, on the triumphal arch and the connection between it and the walls surrounding.
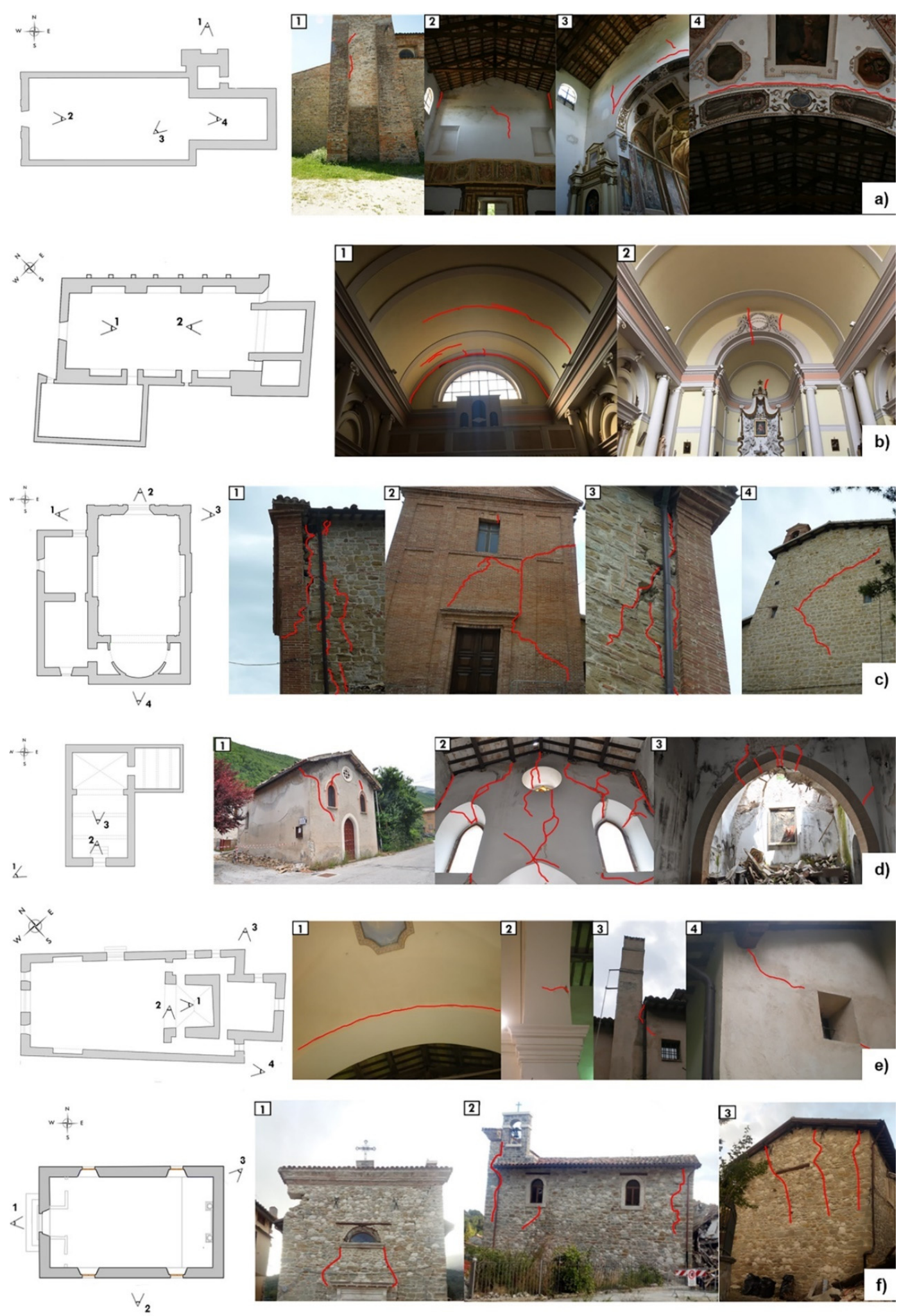

Figure 2. Main damages in: San Francesco Church in Montefortino (a), San Francesco Church in Sarnano (b), Sant'Anna Church in Camerino (c), Sant'Antonio Church in Ussita (d), Madonna of Valcora Sanctuary in Fiuminata (e), Santissimo Crocifisso in Arquata del Tronto (f). 


\subsection{San Francesco Church in Sarnano (Marche Region, Macerata Province)}

The San Francesco church was built in the 14th century. It was renovated in 1833 and a light barrel vault was placed thanks to a general elevation of $4 \mathrm{~m}$, finally adding some Ionic columns. The building has a unique nave of dimensions $22.87 \mathrm{~m} \times 11.26 \mathrm{~m}$ (length $\times$ width) with a maximum height of $16 \mathrm{~m}$ and the tower has dimensions of $5 \mathrm{~m} \times 6.5 \mathrm{~m}$ and a height of $28 \mathrm{~m}$. A little rectangular chapel of $12.34 \mathrm{~m} \times 6.95 \mathrm{~m}$ (length $\times$ width) relates to the church on the south-west. The church has a timber roof. The church's walls are realized by disordered rubble stone masonry covered by a solid bricks' masonry layers. The church underwent renovations between 2014-2015.

During the seismic sequence of 2016 suffered minor damage (v. Figure 2b). Different cracks appeared on the nave's light camorcanna vault both in the middle and near the façade, although little cracks are noticeable on the apse's light barrel vault and on the triumphal arch.

\subsection{Sant'Anna Church in Camerino (Marche Region, Macerata Province)}

The church's unique nave of $14.92 \mathrm{~m} \times 8.53 \mathrm{~m}$ (length $\times$ width) has a maximum height of $16 \mathrm{~m}$. The walls' thicknesses are between $0.7-0.8 \mathrm{~m}$. Disordered rubble stone masonry composed the main walls, as well as in the previously described case study; the façade is covered by brick masonry. The triumphal arch, embedded in a brickwork board, separates the apse from the nave area. A rectangular annex is placed in on side of the church, with dimensions of $12.18 \mathrm{~m} \times 4.29 \mathrm{~m}$ and a height of $8.46 \mathrm{~m}$. The current features are due to the heavy collapses suffered during the earthquake of 1799. Subsequently, after the seismic sequence of 1997, the church showed structural failure of the foundation, then restored in 1999.

During the seismic sequence of 2016, the façade was affected by heavy cracks (Figure 2c) mainly due by the activation of a composed overturning mechanism, with cracks that appeared between it and the nave's walls and along it. Diagonals cracks also appeared on the south façade.

\subsection{Sant'Antonio Church in Ussita (Marche Region, Macerata Province)}

The little church of Sant'Antonio was built during the 17th century. A unique rectangular nave $(10.96 \mathrm{~m} \times 6.25 \mathrm{~m})$ characterizes the church with a maximum height of $7 \mathrm{~m}$. The walls' thickness is about $0.60 \mathrm{~m}$. Disordered rubble stone masonry composes the main walls. The nave and the apse are isolated by a triumphal arch with a gothic molding. The church is covered by a wooden roof and a light vault is placed in the apse. An annex used as a sacristy is placed in one side. It has dimensions of $4.3 \mathrm{~m} \times 4.4 \mathrm{~m}$ and height of $3.6 \mathrm{~m}$. It suffered several damages during through the years, mainly referred to the Umbria-Marche seismic sequence of 1997.

Sant'Antonio's church is one of the two most damaged churches among the six analyzed since it is very near to the epicenter of the event occurred on the 26 October 2016. Extensive damages are present in all its walls. The collapse of the ball-gable led to the failure of the apse. A smeared cracking of the façade near the windows, and on the connection between the nave's walls completes the report of the damages (Figure 2d).

\subsection{Madonna of Valcora Sanctuary in Fiuminata (Marche Region, Macerata Province)}

The church is located in a hamlet of Fiuminata. It was built in the first half of the 15 th century and successively extended in 1728 . The sanctuary has a single nave with dimensions $16.2 \mathrm{~m} \times 9.16 \mathrm{~m}$ (length $\times$ width) with a gable roof. The walls' thicknesses range between $0.5 \mathrm{~m}$ to $0.8 \mathrm{~m}$. Limestone masonry composes the main walls.

During the seismic sequence that stroke Central Italy in 2016, major cracks appeared on the barrel vault of the apse. Minor cracks are widespread all over the complex. An overturning mechanism is also activated due to the presence of a crack between the church and the bell-gable (see Figure 2e). 


\subsection{Santissimo Crocifisso in Arquata del Tronto (Marche Region, Ascoli Piceno Province)}

The church of Santissimo Crocifisso is located in a hamlet of Arquata del Tronto. The first documents date back to the 15th century. It has a unique nave of $11.94 \mathrm{~m} \times 7.24 \mathrm{~m}$ (length $\times$ width). The façade has essential features, with a travertine stone gate and a big window above it. Disordered rubble stone masonry composes the main walls. During its life, it has suffered several damages from intense earthquakes; thus, it underwent subsequent restorations. The Umbria-Marche seismic sequence of 1997 heavily damaged the church. Between the years 2014-2015, a seismic retrofitting was executed using the restoration technique of unstitching and stitching of the masonry walls, introducing curb steel on the principal façade and reinforcing the camorcanna vaults. At the same time, the recesses were reopened, and a new wood roof was built.

During the Central Italy seismic sequence of 2016, different overturning mechanisms were activated in the façades, and several collapses were observed due to disintegrations of the walls (v. Figure 2f).

\section{The Numerical Models}

The numerical models are realized in accordance to a detailed relief of the variations in walls' thicknesses, on geometrical and structural irregularities and on wall connections. Finally, the main openings of the churches are reproduced (Figure 3).

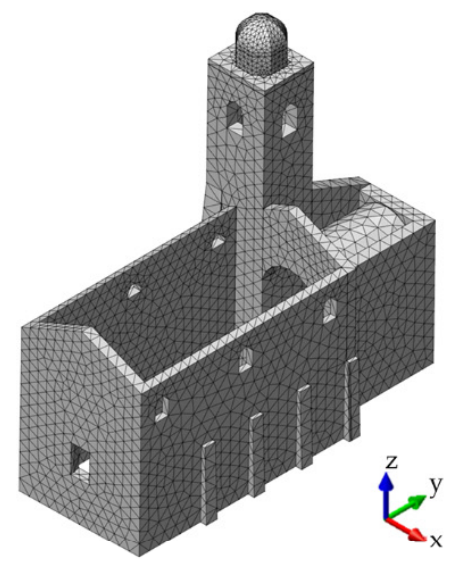

a)

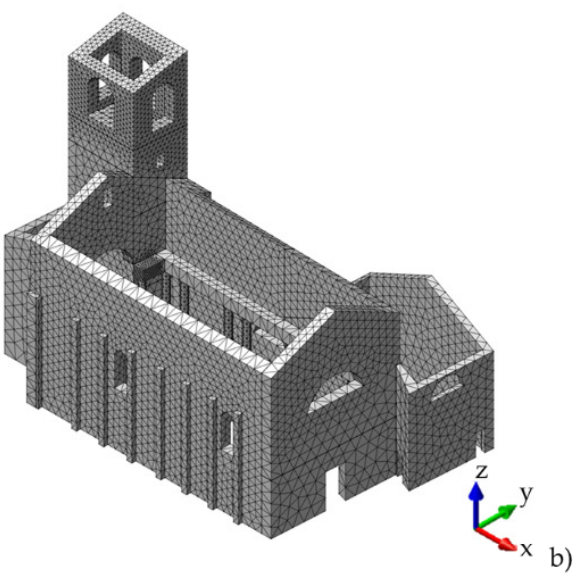

b)

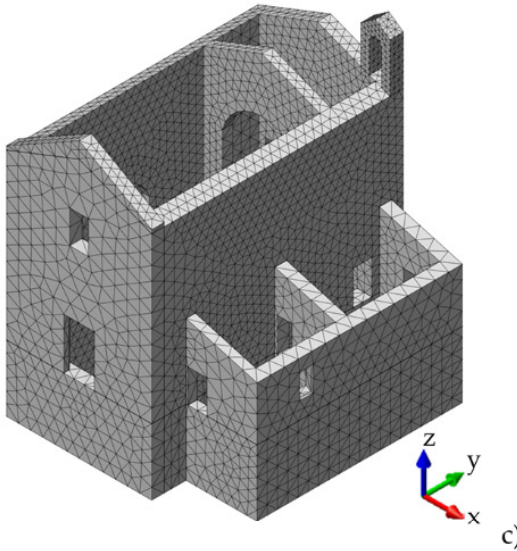

c)

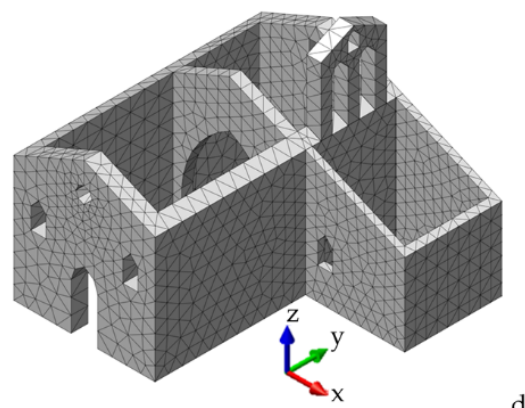

d)

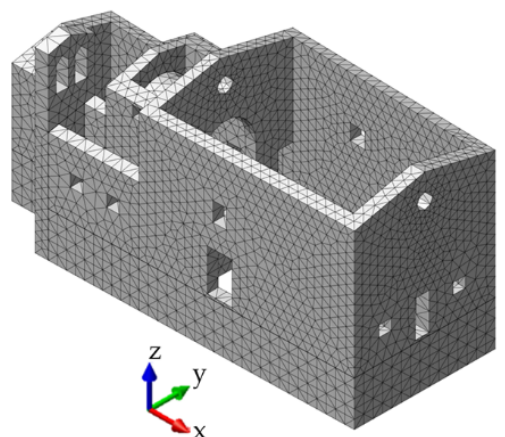

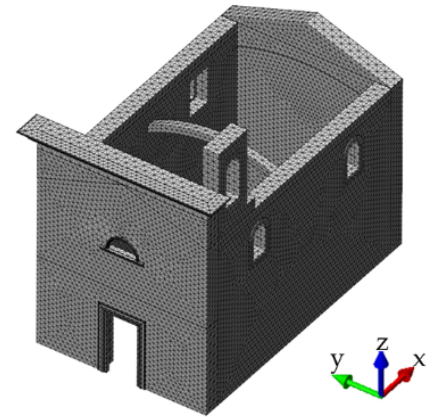

e)

Figure 3. Numerical models of San Francesco Church in Montefortino (a), San Francesco Church in Sarnano (b), Sant'Anna Church in Camerino (c), Sant'Antonio Church in Ussita (d), Madonna of Valcora Sanctuary in Fiuminata (e), Santissimo Crocifisso in Arquata del Tronto (f).

The characterization of the materials strictly follows the data collected during the surveys, and the main mechanical parameters are taken directly from Italian Regulations [3,4]. In Table 1, the main characteristics of the numerical models of the six churches analyzed are synthetized. 
Table 1. Main characteristics of the numerical models of the six churches analyzed.

\begin{tabular}{cccc}
\hline Church & Elements & Nodes & Degrees of Freedom \\
\hline San Francesco Church in Montefortino & 16,466 & 5243 & 15,033 \\
\hline San Francesco Church in Sarnano & 57,889 & 16,623 & 48,516 \\
\hline Sant'Anna Church in Camerino & 29,706 & 8471 & 24,336 \\
\hline Sant'Antonio Church in Ussita & 5642 & 1859 & 6597 \\
\hline Madonna of Valcora Sanctuary in Fiuminata & 24,814 & 7358 & 20,964 \\
\hline Santissimo Crocifisso in Arquata del Tronto & 169,935 & 38,499 & 112,899 \\
\hline
\end{tabular}

In this paper, the nonlinear behavior of the masonry is considered within a continuum mechanics theory, based on a smeared crack approach implemented in MIDAS FEA@ where the cracks are not labelled one by one but are in its place continuously spread inside the continuum affecting (reducing) the average stiffness [30]. The used macromodelling technique offers a variety of possibilities, ranging from fixed single to fixed multidirectional and rotating crack approaches. Here, the distinction lies in the orientation of the crack, which is either kept constant, updated in a stepwise manner, or updated continuously [31,32].

The masonry's complex behavior is considered by the selected constitutive laws: in compression by means of a parabolic hardening rule and a parabolic softening branch following the peak of resistance, while in tension by a linear hardening branch followed by a nonlinear softening branch (see Figure 4). The fracture energies in compression $\left(G_{c}\right)$ and tension $\left(G_{f}\right)$ are reported in Table 2, and $h$ is the mean dimension of the mesh. The shear retention factor $(\beta)$ gives the shear stiffness after cracking, which can be a constant (low) value between 0 and 1 , or a value depending on the crack opening. Here, a constant value equal to 0.05 was adopted like requested in [31]. For a broader and more detailed use of the method, see $[12,13,30,33]$.

Table 2. Mechanical characteristics of the main elements of the numerical models of the six churches analyzed.

\begin{tabular}{|c|c|c|c|c|c|c|c|c|}
\hline Church & $\begin{array}{c}f_{m} \\
(\mathbf{M P a})\end{array}$ & $\begin{array}{c}f_{t} \\
(\mathbf{M P a})\end{array}$ & $\begin{array}{c}\gamma_{\mathrm{v}} \\
\left(\mathrm{kN} / \mathrm{m}^{3}\right)\end{array}$ & $\begin{array}{c}\mathrm{E} \\
(\mathrm{MPa})\end{array}$ & $\begin{array}{c}v \\
(-)\end{array}$ & $\begin{array}{c}G_{c} \\
(\mathrm{~N} / \mathrm{mm})\end{array}$ & $\begin{array}{c}G_{f} \\
(\mathrm{~N} / \mathrm{mm})\end{array}$ & $\begin{array}{c}h \\
(\mathrm{~mm})\end{array}$ \\
\hline San Francesco Church in Montefortino & 0.741 & 0.074 & 18 & 870 & 0.49 & 0.938 & 0.009 & 400 \\
\hline San Francesco Church in Sarnano & 2.000 & 0.200 & 22 & 1500 & 0.49 & 1.880 & 0.019 & 700 \\
\hline Sant'Anna Church in Camerino & 0.741 & 0.074 & 19 & 870 & 0.49 & 0.938 & 0.009 & 400 \\
\hline Sant'Antonio Church in Ussita & 1.007 & 0.101 & 18.5 & 948 & 0.49 & 1.163 & 0.012 & 200 \\
\hline Madonna of Valcora Sanctuary in Fiuminata & 1.007 & 0.101 & 18.5 & 948 & 0.49 & 1.163 & 0.012 & 200 \\
\hline Santissimo Crocifisso in Arquata del Tronto & 1.482 & 0.148 & 20 & 1230 & 0.40 & 1.524 & 0.015 & 200 \\
\hline
\end{tabular}

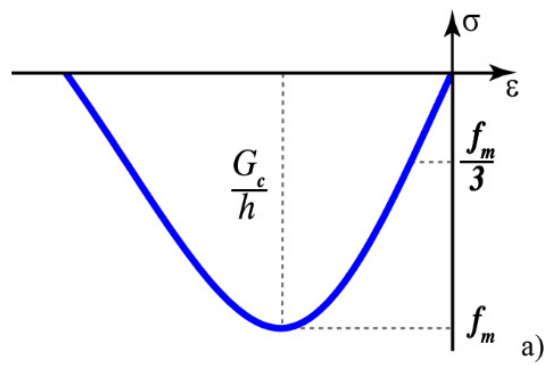

a)

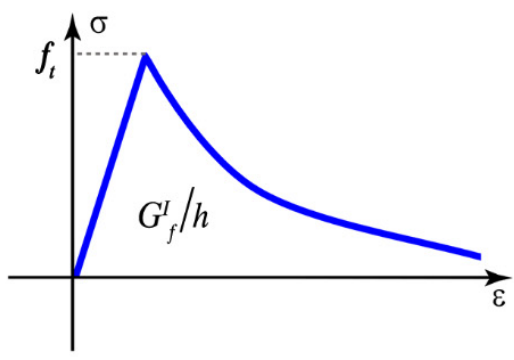

b)

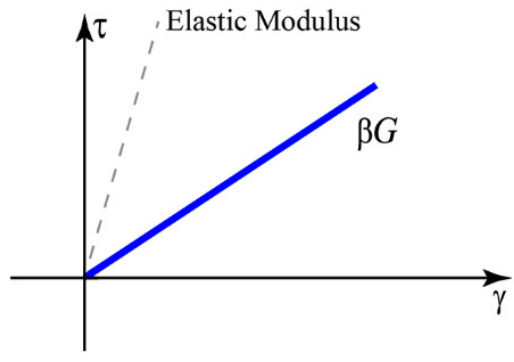

c)

Figure 4. Stress-strain constitutive relations used for the simulations: masonry uniaxial compression (a), masonry uniaxial tension $(\mathbf{b})$, shear behavior $(\mathbf{c})$. 
The main mechanical parameters are assumed according to Table C8.5.I of [4], for the knowledge level 1, and they are reported in Table 2.

\subsection{Eigenfrequency Analysis}

An eigenfrequency analysis is firstly performed on the 3D FE models to identify the main frequencies, the related modal shapes and the effective modal masses $\left(\% \mathrm{M}_{\mathrm{eff}}\right)$ of each mode of the six considered Apennine Churches. We opted for the Block Lanczos method to estimate the modal shapes, as we need to consider different modes to have more than $85 \%$ of excited mass, since churches are generally affected by many local modes:

- 34 modes for San Francesco Church in Montefortino;

- 271 modes San Francesco Church in Sarnano;

- 30 modes Sant'Anna Church in Camerino;

- 28 modes for Sant'Antonio Church in Ussita;

- 40 modes Madonna of Valcora Sanctuary in Fiuminata;

- 52 modes for Santissimo Crocifisso in Arquata del Tronto.

In order to have a first insight on the churches' most vulnerable to seismic actions areas, while remaining in the linear elastic field, the frequencies of the six churches will be compared with the spectra obtained from the accelerations recorded in the three epicenters of the seismic sequence of central Italy in 2016:

- 24 August 2016 Amatrice with $\mathrm{M}_{\mathrm{L}}=6.0$ and $\mathrm{M}_{\mathrm{W}}=6.0$ (AMT station in Italian Accelerometric Archive (ITACA)),

- 26 October 2016 Campi with $\mathrm{M}_{\mathrm{L}}=5.9$ and $\mathrm{M}_{\mathrm{W}}=5.9$ (CMI station in ITACA),

- 30 October 2016 Forca Canapine $\mathrm{M}_{\mathrm{L}}=6.1$ and $\mathrm{M}_{\mathrm{W}}=6.5$ (FCC station in ITACA).

The spectra are freely accessible from the site http:/ /itaca.mi.ingv.it/ItacaNet_30/\#/home.

\subsubsection{San Francesco Church in Montefortino}

It can be noted (see Figure 5$)$ that the first $(T=0.497 \mathrm{~s})$ and second $(T=0.396 \mathrm{~s})$ modes involve mainly the belfry with the largest $\% \mathrm{M}_{\text {eff }}$ equal to $30.69 \%$ and $21.41 \%$ in the north and east directions, respectively. The other modes with higher participation masses are the sixth mode ( $T=0.182 \mathrm{~s})$ that is quite spread $\left(\% \mathrm{M}_{\text {eff }}\right.$ is $12.33 \%$ in north and $13.78 \%$ in east directions) involving the main façade, the belfry, and the apse. The seventh mode $(T=0.179 \mathrm{~s})$ is always spread like the sixth but presents a main $\% \mathrm{M}_{\text {eff }}$ in the north direction equal to $26.76 \%$. The main modes corresponding to the acceleration's peaks, involved separately the nave's walls and the façade but are not reported in Figure 5 only for sake of clarity. The $\% \mathrm{M}_{\text {eff }}$ are always around $10 \%$ and, therefore, they are not negligible, being carriers of very localized damage that can activate classic overturning mechanisms.

\subsubsection{San Francesco Church in Sarnano}

The main period and modal shapes are reported in Figure 6 . The first $(T=0.281 \mathrm{~s})$ and third modes $(T=0.214 \mathrm{~s}$ ) involve mainly the belfry and the nave's wall, and they are associated with a $\% \mathrm{M}_{\text {eff }}$ equal to $18.62 \%$ in north and $14.41 \%$ in east directions, respectively. They are close to the peaks of acceleration which involves a possible localized damage in these portions. The third mode seems very dangerous for both the triumphal arch and the bell cell. 
Mode n.7, $\mathrm{T}=0.179 \mathrm{~s}$

Mode n.1, $\mathrm{T}=0.497 \mathrm{~s}$

$M_{\text {eff }}$ North $=4.60 \%$

$\mathrm{M}_{\text {eff }}$ East $=26.76 \%$

$M_{\text {eff }}$ North $=30.69 \%$

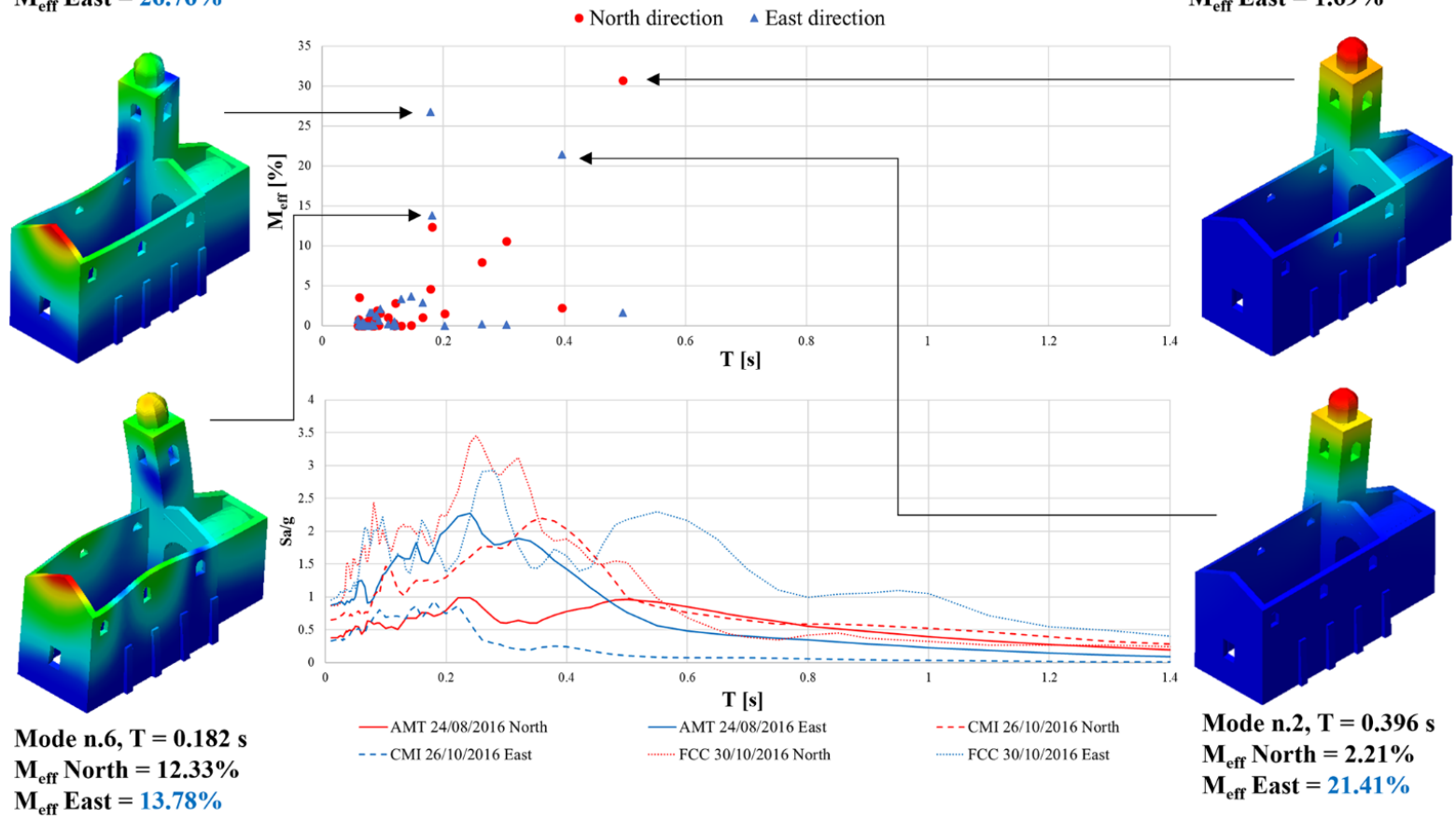

Figure 5. Distribution of modal shapes in the longitudinal and transversal directions and comparison with the pseudoacceleration response spectra of the three main shocks of Central Italy seismic sequence of 2016 for San Francesco Church in Montefortino (Fermo, Central Italy).

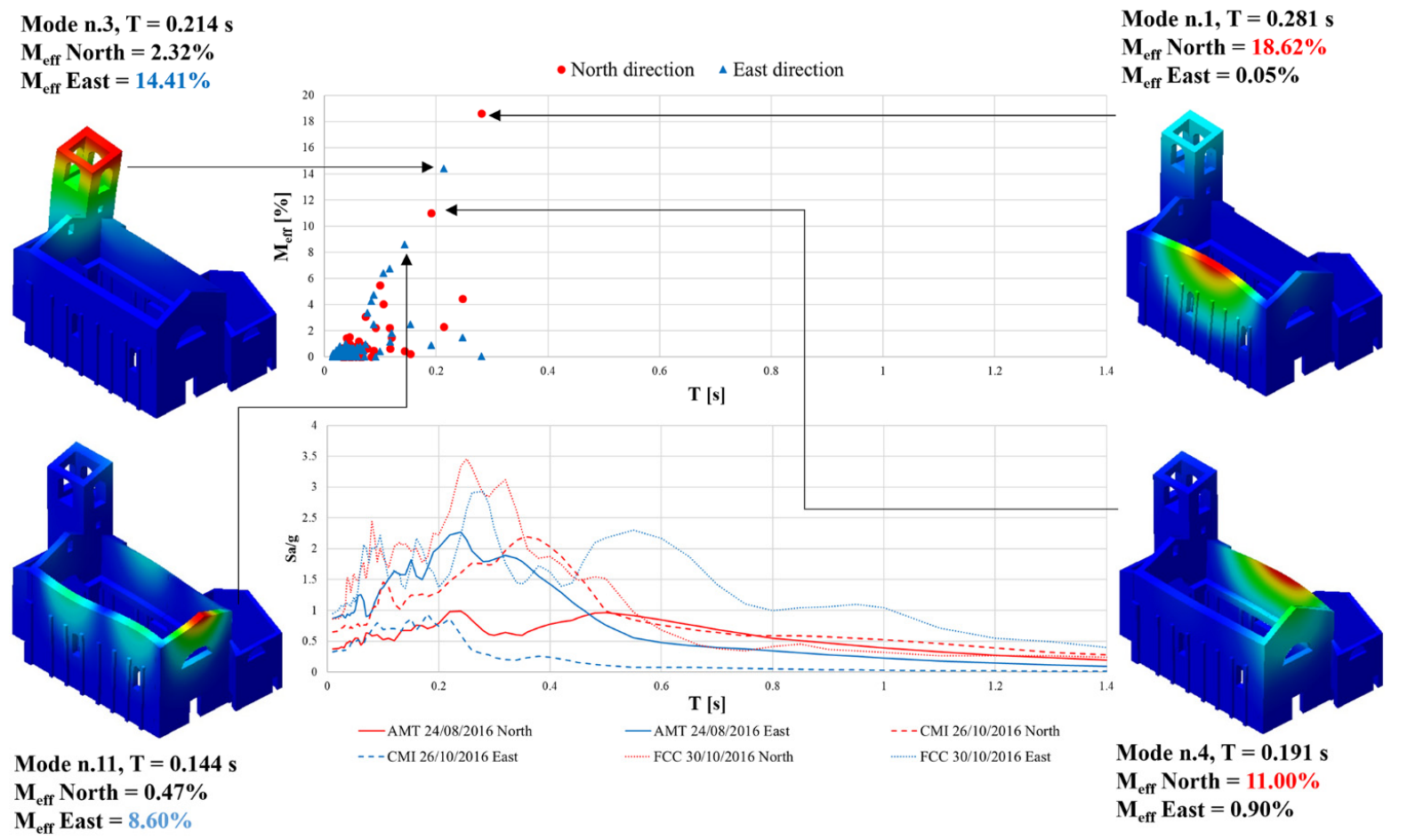

Figure 6. Distribution of modal shapes in the longitudinal and transversal directions and comparison with the pseudoacceleration response spectra of the three main shocks of Central Italy seismic sequence of 2016 for San Francesco Church in Sarnano (Macerata, Central Italy). 
The other modes with higher participation masses are the fourth $(T=0.191 \mathrm{~s})$ and the eleventh $(T=0.144 \mathrm{~s})$ that involve mainly the façade and the two nave's walls $\left(\% \mathrm{M}_{\mathrm{eff}}\right.$ is $11 \%$ in north and $8.60 \%$ in east directions) involving the main façade, the belfry, and the apse. The $\% \mathrm{M}_{\text {eff }}$ is for both around $10 \%$ and, therefore, they are not negligible, being carriers of very localized damage that can activate classic overturning mechanisms.

\subsubsection{Sant'Anna Church in Camerino}

The main period and modal shapes are reported in Figure 7 . The first $(T=0.272 \mathrm{~s})$ and second ( $T=0.214 \mathrm{~s}$ ) modes involve the nave in the two orthogonal directions in plan and are characterized by a $\% \mathrm{M}_{\text {eff }}$ equal to $56.01 \%$ in east and $45.59 \%$ in north directions, respectively. They are close to the peaks of acceleration which involve a possible localized damage. In both modes, the most vulnerable elements are the facade and the bell gable.

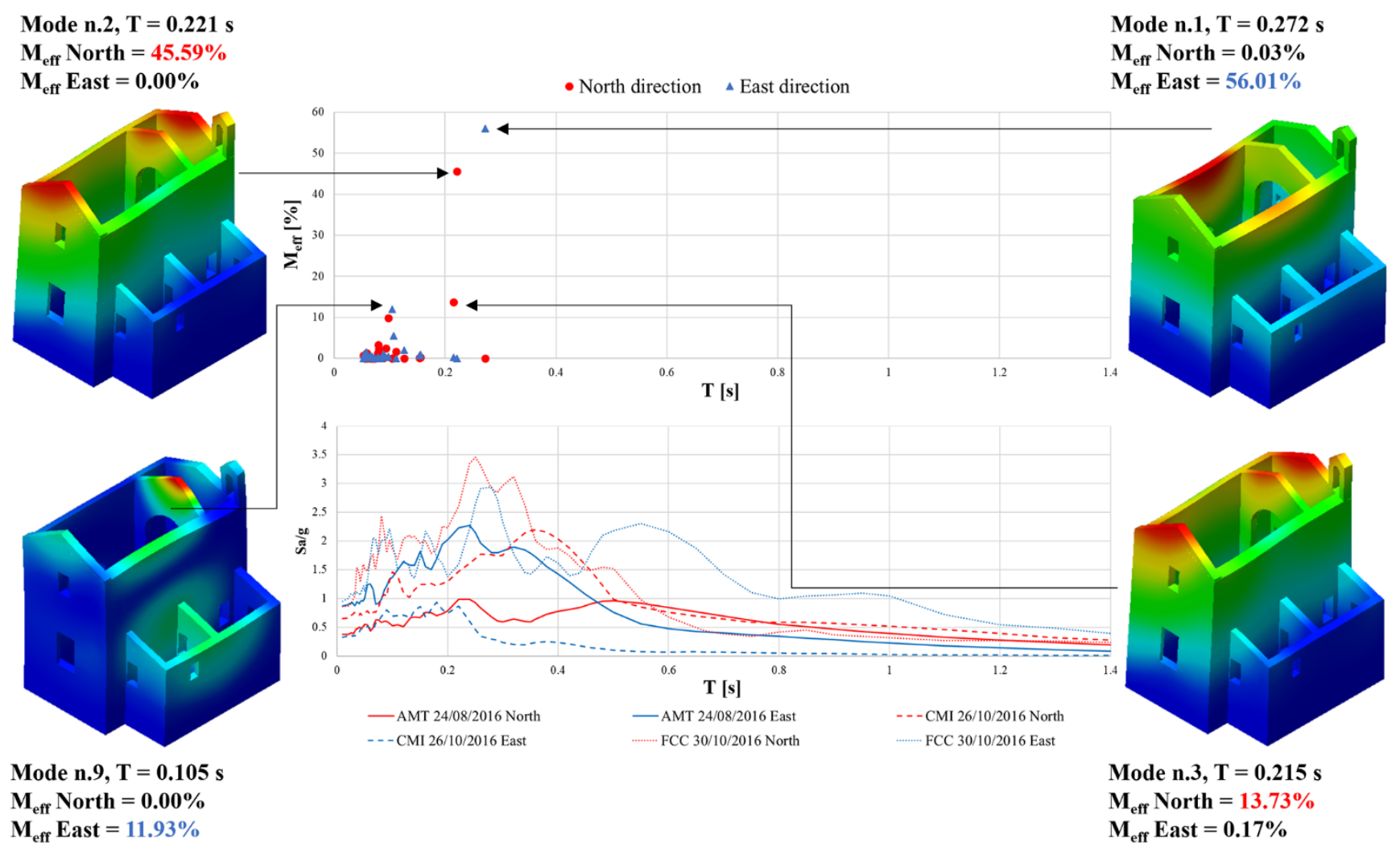

Figure 7. Distribution of modal shapes in the longitudinal and transversal directions and comparison with the pseudoacceleration response spectra of the three main shocks of Central Italy seismic sequence of 2016 for Sant'Anna Church in Camerino (Macerata, Central Italy).

The other modes with higher participation masses are the third $(T=0.215 \mathrm{~s})$ and the ninth $(T=0.105 \mathrm{~s})$, mainly involving the façade and the triumphal arch $\left(\% \mathrm{M}_{\mathrm{eff}}\right.$ is $13.73 \%$ in north and $11.93 \%$ in east directions). The $\% \mathrm{M}_{\text {eff }}$ is for both around $12 \%$ and, therefore, they are not negligible, carrying very localized damage that can activate the most common overturning mechanisms.

\subsubsection{Sant'Antonio Church in Ussita}

The main period and modal shapes are reported in Figure 8 . The second $(T=0.088 \mathrm{~s})$ and third ( $T=0.085 \mathrm{~s}$ ) modes involve the nave in the two orthogonal directions in plan and are characterized by the biggest $\% \mathrm{M}_{\text {eff }}$ equal to $60.03 \%$ in north and $33.79 \%$ in east directions, respectively. Given the small size of the church, both in plan and in height, it is much rigid than the previous ones and, for this reason, the main modes are not positioned near the peaks of spectral acceleration of the most dangerous shock of 30 October 2016. 
However, they are close to the peaks of the seismic acceleration of 26 October 2016 whose epicenter was close to the church's location. It is important to stress the fact that the most vulnerable element for the first two modes is the bell gable.

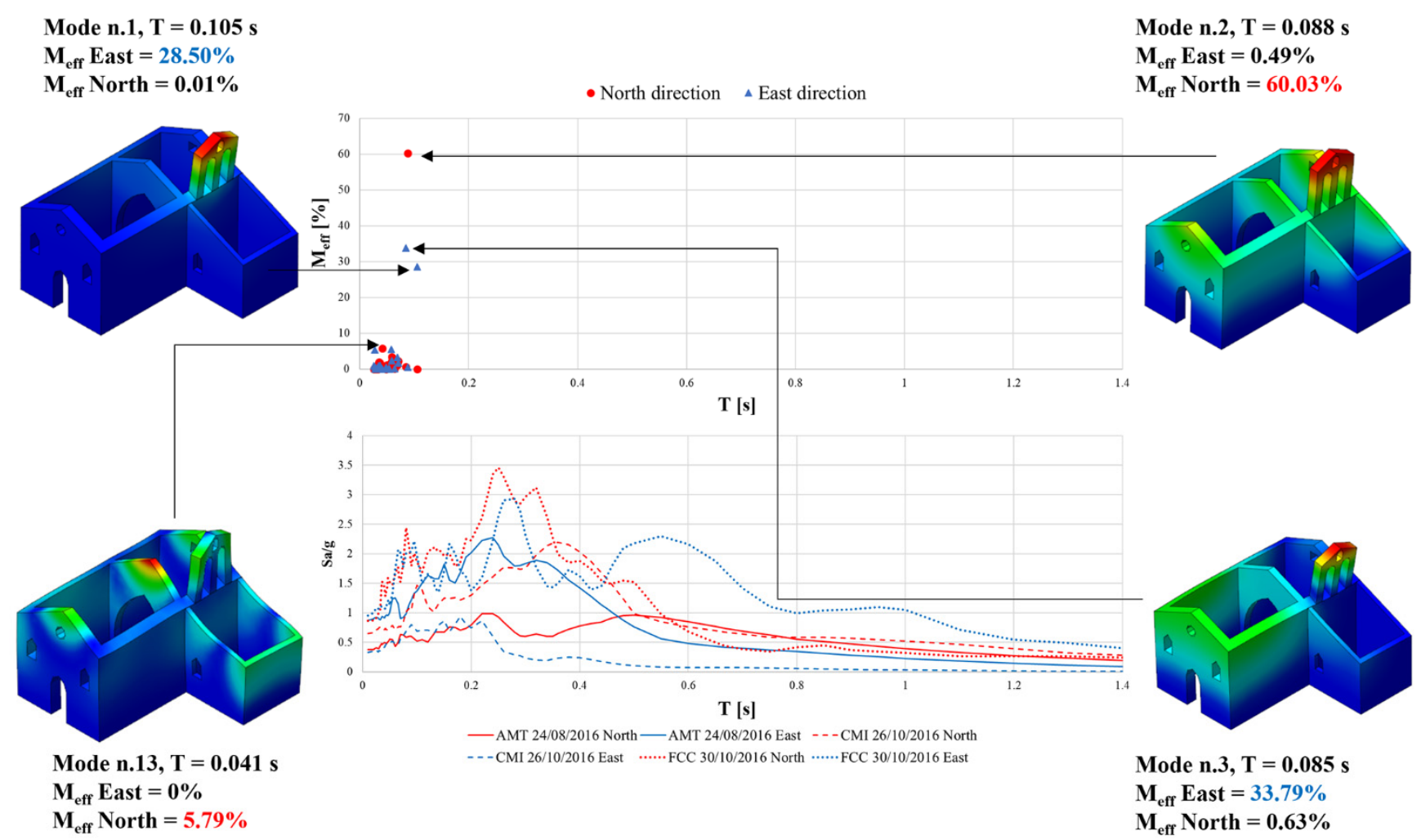

Figure 8. Distribution of modal shapes in the longitudinal and transversal directions and comparison with the pseudoacceleration response spectra of the three main shocks of Central Italy seismic sequence of 2016 for Madonna of Sant'Antonio Church in Ussita (Macerata, Central Italy).

The other modes with higher participation masses are the first $(T=0.105 \mathrm{~s})$ and the thirteenth $(T=0.041 \mathrm{~s})$ that involve mainly the bell gable and the triumphal arch $\left(\% \mathrm{M}_{\text {eff }}\right.$ is $28.5 \%$ in east and $5.79 \%$ in north directions). There are very localized modal shapes that, even in these cases, can activate classic overturning mechanisms, as their periods are always very close to the peaks of the shock of 26 October 2016.

\subsubsection{Madonna of Valcora Sanctuary in Fiuminata}

The main period and modal shapes are reported in Figure 9. The first $(T=0.234 \mathrm{~s})$ and fourth $(T=0.143 \mathrm{~s})$ modes involve the nave in the two orthogonal directions in plan and are characterized by the biggest $\% \mathrm{M}_{\text {eff }}$ equal to $36.66 \%$ in north and $52.79 \%$ in east directions, respectively. This is a more rigid church respect to Montefortino and Sarnano and it is characterized by short periods close to the peaks of the seismic acceleration of 26th October 2016. It is important to stress the fact that the most vulnerable element for the first two modes are the nave's walls, the triumphal arch and the façade.

The other modes with higher participation masses are the fifth $(T=0.134 \mathrm{~s})$ and the thirteen ( $T=0.087 \mathrm{~s}$ ) that involve mainly the bell gable and nave's wall in the out-of-plane directions $\left(\% \mathrm{M}_{\text {eff }}\right.$ is 16.29 and $7.18 \%$, and both in north directions), and they can activate classic overturning mechanisms. 


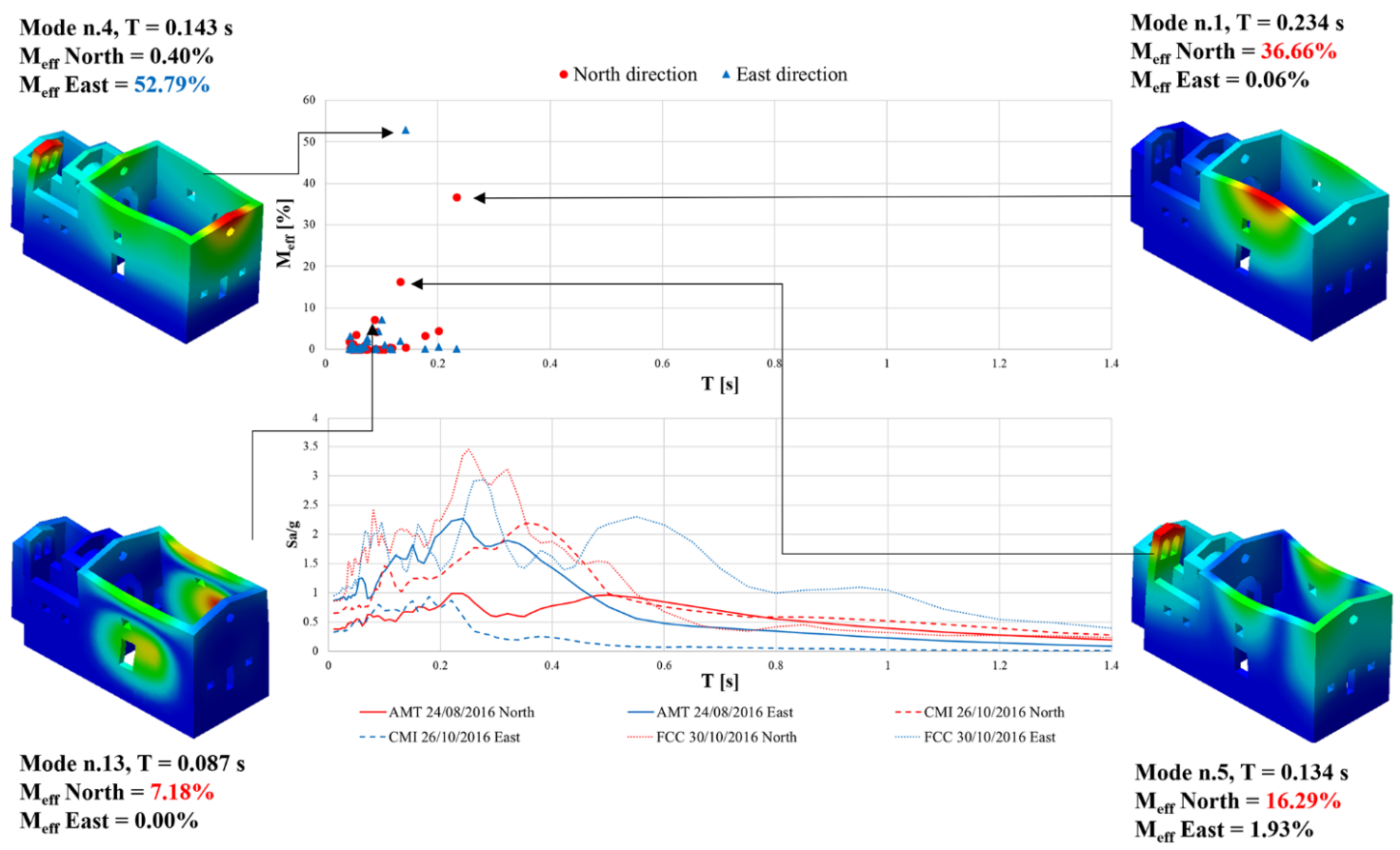

Figure 9. Distribution of modal shapes in the longitudinal and transversal directions and comparison with the pseudoacceleration response spectra of the three main shocks of Central Italy seismic sequence of 2016 for Madonna of Valcora Sanctuary in Fiuminata (Macerata, Central Italy).

\subsubsection{Santissimo Crocifisso Church in Arquata del Tronto}

The main period and modal shapes are reported in Figure 10 . The first $(T=0.219 \mathrm{~s})$ and third $(T=0.144 \mathrm{~s})$ modes involve mainly the nave, the façade and the bell gable and are characterized by a $\% \mathrm{M}_{\text {eff }}$ equal to $38.41 \%$ in east and $27.71 \%$ in north directions, respectively.
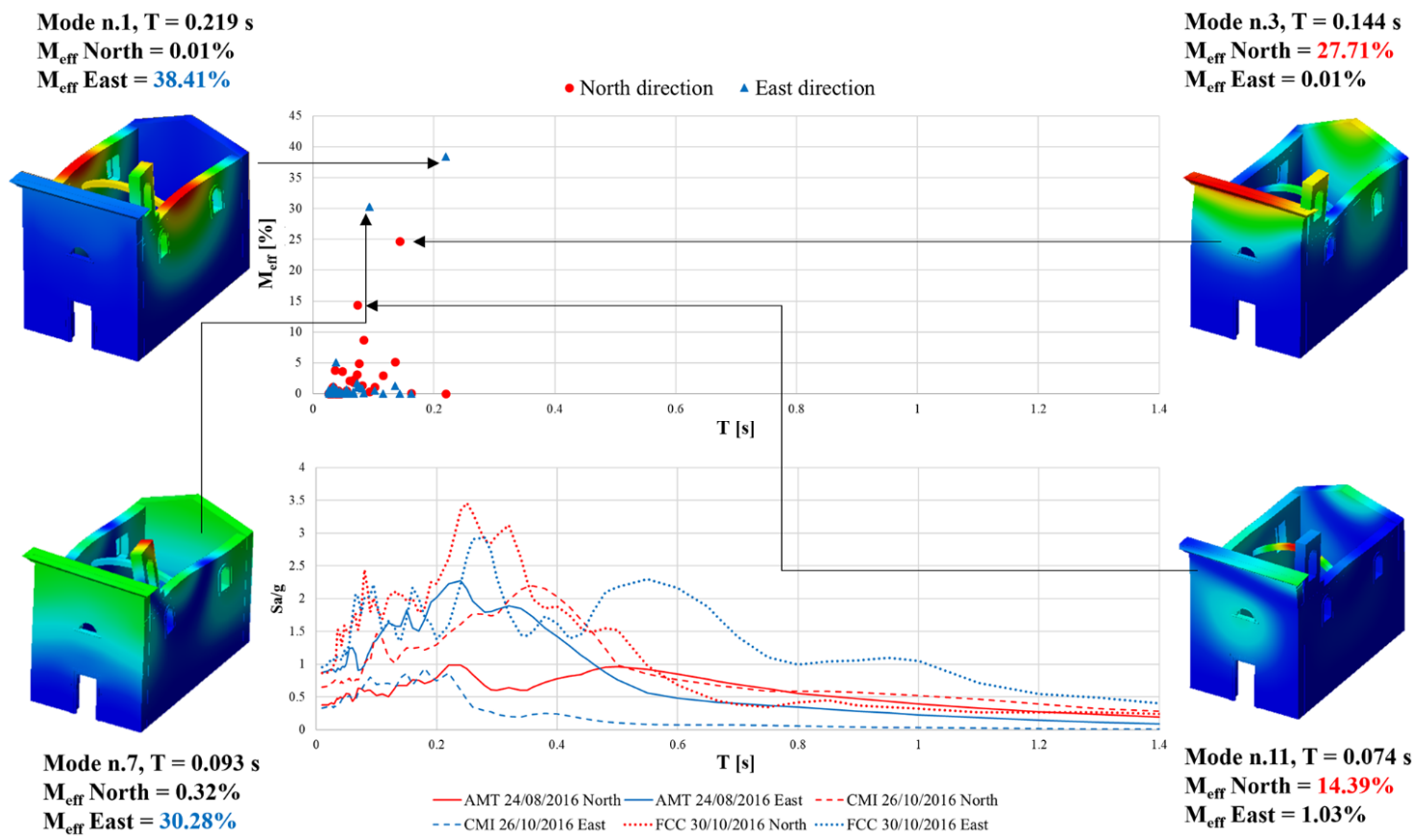

Figure 10. Distribution of modal shapes in the longitudinal and transversal directions and comparison with the pseudoacceleration response spectra of the three main shocks of Central Italy seismic sequence of 2016 for Santissimo Crocifisso church in Arquata del Tronto (Ascoli Piceno, Central Italy). 
The other modes with higher participation masses are the seventh $(T=0.093 \mathrm{~s})$ and the eleventh $(T=0.074 \mathrm{~s})$ that involve mainly the bell gable and the facade in the out-of-plane directions ( $\% \mathrm{M}_{\text {eff }}$ is 30.28 and $14.39 \%$ in east and in north directions, respectively), and they can activate classic overturning mechanisms, given the concomitance of the structural periods with that of the spectral acceleration peaks.

\section{Damage Assessment by Nonlinear Static Analysis}

The nonlinear static analysis method, also known as pushover analysis, was used to properly analyze the seismic behavior of the six churches, by monotonically increasing horizontal loads and keeping gravity loads constant. A total of two systems of perpendicular horizontal forces, acting at different times, were used to consider seismic loads. These systems lead to two load distributions that may be considered two limit states of the building capacity, one related to the masses on each floor by direct proportion (PushMass) and one equivalent to the superposition of main modes involving at least the $85 \%$ of participating masses in both directions (PushMode).

As can be clearly remarked by considering the above described load distributions, the pushover analysis performed is merely conventional, i.e., loads applied to the building are kept constant while the structure progressively degrades during the loading, so gradual changes in modal frequencies caused by yielding and cracking on the structure during loading are not considered. Even though the invariance of static loads may lead to an overestimation in assessing masonry buildings' seismic capacity, mostly on structures affected by a high or non-uniform impairment, a conventional pushover analysis ensures a less computationally expensive alternative to nonlinear dynamic analyses. It also provides substantial data on the progressive damage occurring to buildings under seismic loads, such as cracking.

In the following sections, a comparison between the real and the numerical damages is reported, and discussed, in order to assess the numerical methods and the main vulnerabilities of the six analyzed churches.

\subsection{San Francesco Church in Montefortino}

The nonlinear static analyses confirm the results obtained from the eigenvalue analysis. Widespread damage, with the probable occurrence of an active failure mechanism, is registered in the upper part of the walls of the façade and the apse, see Figure 11, confirming this area as the most vulnerable one. A heavy numerical damage is evident at the interface between the triumphal arc and the apse's vault, in the middle of the triumphal arc, and in the connection between the belfry and the nave's wall, and immediately over the main entrance with a quasi-vertical crack in the main façade. All numerical damages properly reproduce what is reported in Figure $2 \mathrm{a}$.

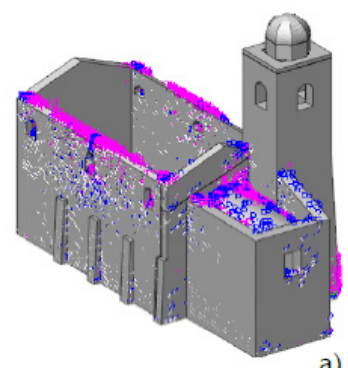

a)

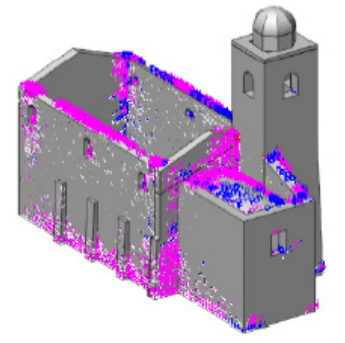

b)

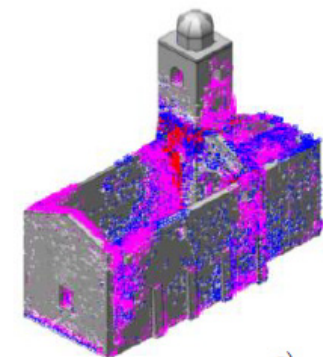

c)

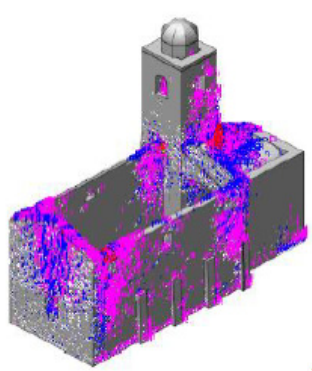

d)

Figure 11. Numerical damage for San Francesco Church in Montefortino (Fermo, Central Italy) for PushMass $+x(a)$, PushMass $-\mathrm{x}(\mathbf{b})$, PushMass $+\mathrm{y}(\mathbf{c})$, PushMass $-\mathrm{y}(\mathbf{d})$. 


\subsection{San Francesco Church in Sarnano}

Widespread damage, with the probable occurrence of an active failure mechanism, is registered in the upper part of the walls of the façade, of the nave's walls, and of the apse, see Figure 12, confirming the results obtained from the eigenvalue analysis. A heavy numerical damage, always obtained with nonlinear static analysis, is evident in the connection between the belfry and the nave's wall, and immediately over the windows of the façade with a quasi-vertical crack in the middle. The bell cell presents cracks in the columns, and in general the nonlinear static analysis well replicates what is reported in Figure $2 b$.
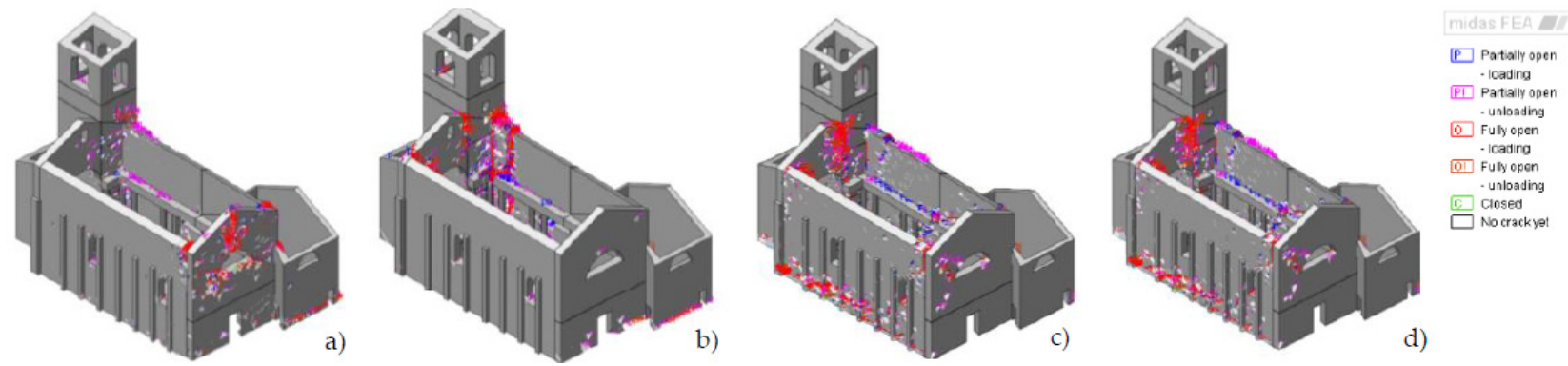

Figure 12. Numerical damage for San Francesco Church in Sarnano (Macerata, Central Italy) for PushMass $+x(a)$, PushMass $-x$ (b), PushMass + y (c), PushMass - y (d).

\subsection{Sant'Anna Church in Camerino}

A clear diagonal crack in the main façade is correctly reproduced, with the probable occurrence of its active failure mechanism, see Figure 13, confirming both the real damage and the results obtained from the eigenvalue analysis. A similar inclined crack in the upper part of the secondary façade is also well reproduced, also with a clear activation of the out-of-plane mechanism of the bell gable. A heavy numerical damage is evident in all the connections between orthogonal walls, with a widespread cracking of the nave's wall not supported by the annex. Even in this case, the nonlinear static analysis well replicates what is reported in Figure 2c.
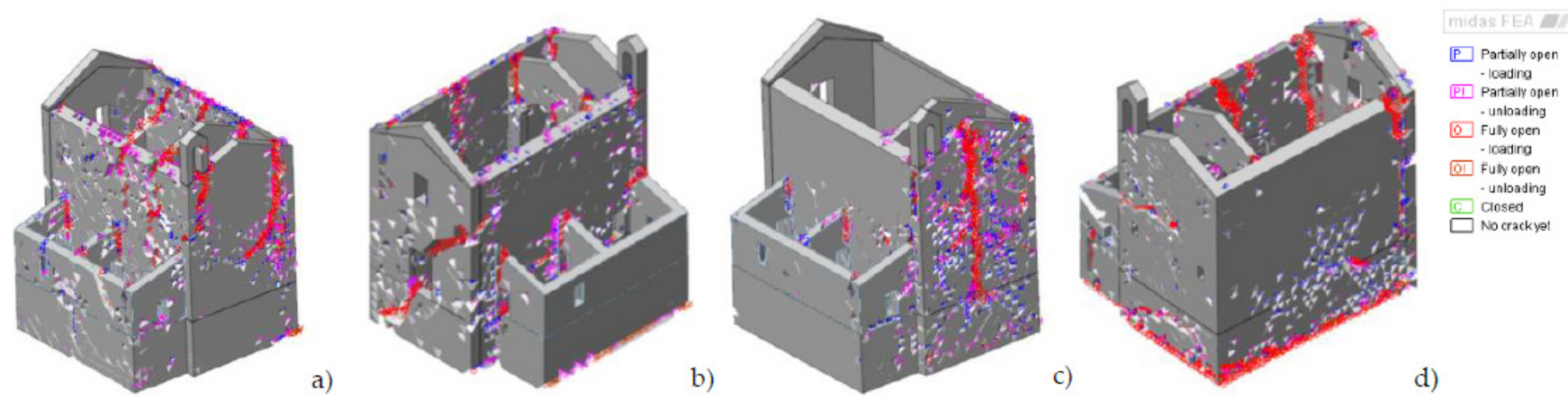

Figure 13. Numerical damage for Sant'Anna Church in Camerino (Macerata, Central Italy) for PushMass $+x(\mathbf{a})$, PushMass $-x(\mathbf{b})$, PushMass $+\mathrm{y}(\mathbf{c})$, PushMass $-\mathrm{y}(\mathbf{d})$.

\subsection{Sant'Antonio Church in Ussita}

The bell gable is always the most vulnerable part of the church, and this is also confirmed by the nonlinear analyses, see Figure 14, and not only by the eigenvalue analysis who see it as the main source of the structural collapse. A heavy numerical damage is evident in all the connections between orthogonal walls, with a widespread cracking of the nave's wall not supported by the annex, this latter clearly damaged in all its walls. 
The main façade presents three main vertical cracks immediately over the openings as also clearly visible in Figure 2d.
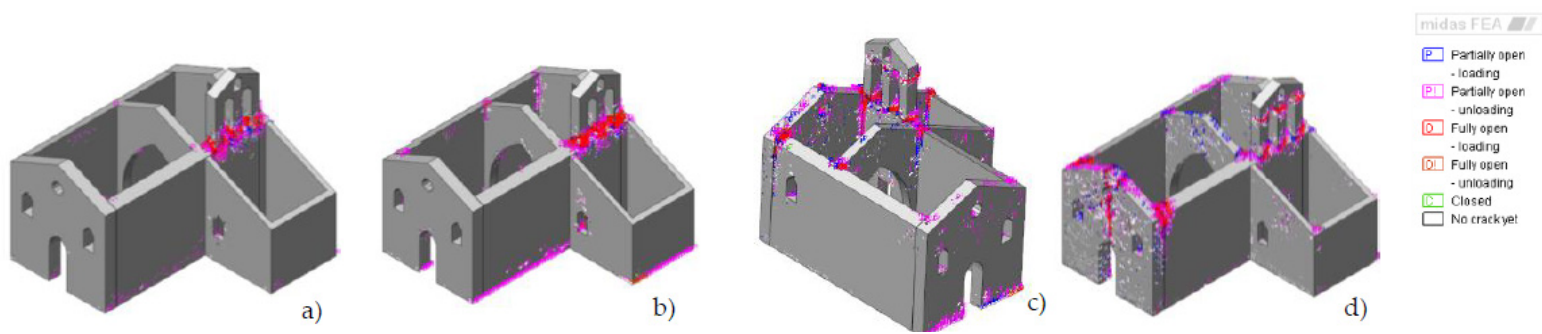

Figure 14. Numerical damage for Sant'Antonio Church in Ussita (Macerata, Central Italy) for PushMass $+x(a)$, PushMass $-x(b)$, PushMass + y (c), PushMass $-\mathrm{y}(\mathbf{d})$.

\subsection{Madonna of Valcora Sanctuary in Fiuminata}

The most damaged points are the main façade in correspondence with the openings which, as previously pointed out, create the trigger for almost vertical cracks (Figure 15). Widespread cracks are present in all the connections between the nave's walls and the façade, confirming once again the overturning mechanism of the facade as the most likely, as well as what affects the bell gable (see Figure 2e). Possible tilting mechanisms can be triggered in the walls of the nave. In this case a direct reference with the real damage is not possible as the site of Valcora suffered attenuated effects given the distance of the epicenters.
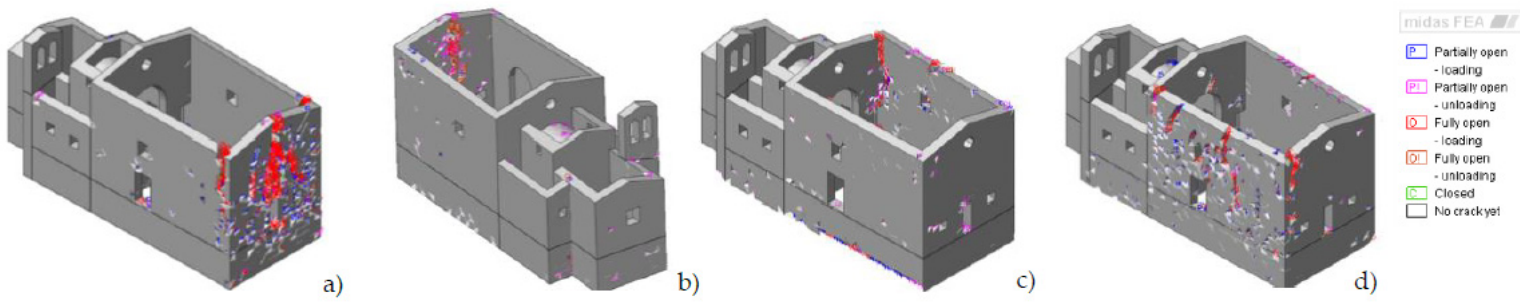

Figure 15. Numerical damage for Madonna of Valcora Sanctuary in Fiuminata (Macerata, Central Italy) for PushMass $+x$ (a), PushMass - x (b), PushMass + y (c), PushMass - y (d).

\subsection{Santissimo Crocifisso in Arquata del Tronto}

Widespread damage, with the probable occurrence of an active failure mechanism, is registered in the upper part of the walls of the façade, of the nave's walls, and of the apse, see Figure 16, confirming the results obtained from the eigenvalue analysis. A heavy numerical damage is evident in the connection between the bell gable and the nave's wall, and a clear activation of an out of plane mechanism of the south façade is also numerically confirmed. In the same wall, clear vertical cracks are replicated by the nonlinear static analysis well as possible compare in Figure 2f.
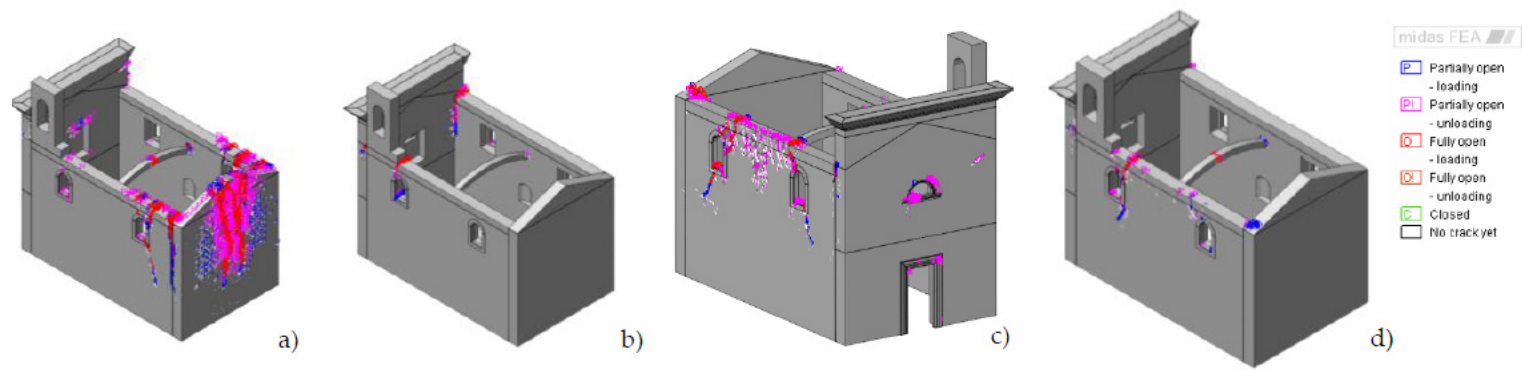

Figure 16. Numerical damage for Santissimo Crocifisso in Arquata del Tronto (Ascoli Piceno, Central Italy) for PushMass $+x$ (a), PushMass $-\mathrm{x}(\mathbf{b})$, PushMass $+\mathrm{y}(\mathbf{c})$, PushMass $-\mathrm{y}(\mathbf{d})$. 


\section{Conclusions}

In the present paper, six masonry churches damaged by the 2016 Central Italy seismic sequence were numerically analyzed. Eigenfrequency analyses are firstly used with real spectra derived by the accelerometer registered near the three epicenters; the nonlinear static analyses are then applied with a smeared crack model, being masonry a material with low tensile strength and softening in tension but also in compression. The final aim of the numerical investigation carried out in this study is to put at disposal the results of a sensitivity analysis led on a satisfactorily great sample to establish if the simplifications adopted in a classical design may be always observed as reliable or not.

The need to analyze several case studies derives from the peculiar characteristics of masonry churches, in particular those of the Apennine area of Central Italy, whose geometric variabilities and irregularities, as well as the architectural intricacy can give a vibrant knowledge on the existence of discrepancy between real and numerical damages. From an overall analysis of the results obtained, the following remarks may be made:

- Classical eigenfrequency analyses associated with natural spectra from real earthquakes can, even qualitatively, identify the possible areas or better macro-blocks that could cause collapse during a seismic event. However, such analyses turn out to be defective when masonry is loaded beyond the elastic limit.

- Nonlinear static analyses appear to be able to represent the failure mechanisms with a more truthful detail, and to replicate case by case the geometric specificities of each church. Despite the large amount of approximations introduced, collapse mechanisms seem in reasonable agreement with reality.

Finally, the presented sensitivity analysis allows asserting that the seismic assessment of such peculiar structures should be always estimated through diverse procedures, including standard eigenfrequency and nonlinear static analyses. All these strategies are affected by different levels of precision and intricacy, but they may eventually lead to a convincing representation of the structural weakness when performed together.

Funding: This research received no external funding.

Data Availability Statement: Not applicable.

Conflicts of Interest: The author declares no conflict of interest.

\section{References}

1. Italian Department of Civil Protection. Terremoto Centro Italia 2016. Available online: http://www.protezionecivile.gov.it/ attivita-rischi/rischio-sismico/emergenze/centro-italia-2016 (accessed on 27 January 2021). (In Italian)

2. Maio, R.; Vicente, R.; Formisano, A.; Varum, H. Seismic vulnerability of building aggregates through hybrid and indirect assessment techniques. Bull. Earthq. Eng. 2015, 13, 2995-3014. [CrossRef]

3. GU Serie Generale n.42 del 20-02-2018-Suppl. Ordinario n. 8. Decreto Ministeriale 17/01/2018-Aggiornamento delle "Norme Tecniche per le Costruzioni"; Ministero delle Infrastrutture e dei Trasporti: Rome, Italy, 2018; pp. 1-198. (In Italian)

4. GU Serie Generale n.35 del 11-02-2019-Suppl. Ordinario n. 5. Circolare 21 gennaio 2019 n. 7 C.S.LL.PP—Istruzioni per l'applicazione dell'Aggiornamento delle "Norme Tecniche per le Costruzioni" di cui al D.M. 17/01/2018; Ministero delle Infrastrutture e dei Trasporti: Rome, Italy, 2019; pp. 1-337. (In Italian)

5. Angelillo, M. Mechanics of Masonry Structures; Angelillo, M., Ed.; CISM International Centre for Mechanical Sciences; Springer Vienna: Vienna, Austria, 2014; Volume 551, ISBN 978-3-7091-1773-6.

6. Pacheco-Torgal, F.; Lourenço, P.B.; Labrincha, J.A.; Kumar, S.; Chindaprasirt, P. Eco-Efficient Masonry Bricks and Blocks: Design, Properties and Durability; Woodhead Publishing: Oxford, UK, 2014; ISBN 978-178242318-8.

7. Berto, L.; Saetta, A.; Scotta, R.; Vitaliani, R. An orthotropic damage model for masonry structures. Int. J. Numer. Methods Eng. 2002, 55, 127-157. [CrossRef]

8. Liberatore, D.; Addessi, D. Strength domains and return algorithm for the lumped plasticity equivalent frame model of masonry structures. Eng. Struct. 2015, 91, 167-181. [CrossRef]

9. Addessi, D.; Sacco, E.; Paolone, A. Cosserat model for periodic masonry deduced by nonlinear homogenization. Eur. J. Mech. A/Solids 2010, 29, 724-737. [CrossRef]

10. Gambarotta, L.; Lagomarsino, S. Damage models for the seismic response of brick masonry shear walls. Part II: The continuum model and its applications. Earthq. Eng. Struct. Dyn. 1997, 26, 441-462. [CrossRef] 
11. Gambarotta, L.; Lagomarsino, S. Damage models for the seismic response of brick masonry shear walls. Part I: The mortar joint model and its applications. Earthq. Eng. Struct. Dyn. 1997, 26, 423-439. [CrossRef]

12. Giordano, E.; Clementi, F.; Nespeca, A.; Lenci, S. Damage Assessment by Numerical Modeling of Sant'Agostino's Sanctuary in Offida during the Central Italy 2016-2017 Seismic Sequence. Front. Built Environ. 2019, 4. [CrossRef]

13. Clementi, F.; Gazzani, V.; Poiani, M.; Mezzapelle, P.A.; Lenci, S. Seismic Assessment of a Monumental Building through Nonlinear Analyses of a 3D Solid Model. J. Earthq. Eng. 2018, 22, 35-61. [CrossRef]

14. Adhikari, R.; Jha, P.; Gautam, D.; Fabbrocino, G. Seismic Strengthening of the Bagh Durbar Heritage Building in Kathmandu Following the Gorkha Earthquake Sequence. Buildings 2019, 9, 128. [CrossRef]

15. Petracca, M.; Pelà, L.; Rossi, R.; Zaghi, S.; Camata, G.; Spacone, E. Micro-scale continuous and discrete numerical models for nonlinear analysis of masonry shear walls. Constr. Build. Mater. 2017, 149, 296-314. [CrossRef]

16. Peruch, M.; Spacone, E.; Camata, G. Nonlinear analysis of masonry structures using fiber-section line elements. Earthq. Eng. Struct. Dyn. 2019, 48, 1345-1364. [CrossRef]

17. Quagliarini, E.; Maracchini, G.; Clementi, F. Uses and limits of the Equivalent Frame Model on existing unreinforced masonry buildings for assessing their seismic risk: A review. J. Build. Eng. 2017, 10, 166-182. [CrossRef]

18. Betti, M.; Vignoli, A. Numerical assessment of the static and seismic behaviour of the basilica of Santa Maria all'Impruneta (Italy). Constr. Build. Mater. 2011, 25, 4308-4324. [CrossRef]

19. Sarhosis, V.; Milani, G.; Formisano, A.; Fabbrocino, F. Evaluation of different approaches for the estimation of the seismic vulnerability of masonry towers. Bull. Earthq. Eng. 2018, 16, 1511-1545. [CrossRef]

20. Lemos, J.V. Discrete Element Modeling of Masonry Structures. Int. J. Archit. Herit. 2007, 1, 190-213. [CrossRef]

21. Casolo, S. Modelling in-plane micro-structure of masonry walls by rigid elements. Int. J. Solids Struct. 2004, 41, 3625-3641. [CrossRef]

22. Poiani, M.; Gazzani, V.; Clementi, F.; Milani, G.; Valente, M.; Lenci, S. Iconic crumbling of the clock tower in Amatrice after 2016 central Italy seismic sequence: Advanced numerical insight. Procedia Struct. Integr. 2018, 11, 314-321. [CrossRef]

23. Ferrante, A.; Clementi, F.; Milani, G. Dynamic Behavior of an Inclined Existing Masonry Tower in Italy. Front. Built Environ. 2019, 5. [CrossRef]

24. Saisi, A.; Gentile, C.; Ruccolo, A. Continuous monitoring of a challenging heritage tower in Monza, Italy. J. Civ. Struct. Health Monit. 2018, 8, 77-90. [CrossRef]

25. Clementi, F.; Pierdicca, A.; Formisano, A.; Catinari, F.; Lenci, S. Numerical model upgrading of a historical masonry building damaged during the 2016 Italian earthquakes: The case study of the Podestà palace in Montelupone (Italy). J. Civ. Struct. Health Monit. 2017, 7, 703-717. [CrossRef]

26. Rainieri, C.; Fabbrocino, G.; Verderame, G.M. Non-destructive characterization and dynamic identification of a modern heritage building for serviceability seismic analyses. NDT E Int. 2013, 60, 17-31. [CrossRef]

27. De Risi, R.; Sextos, A.; Zimmaro, P.; Simonelli, A.; Stewart, J. The 2016 central Italy earthquake sequence: Observations of incremental building damage. In Proceedings of the 11th U.S. National Conference on Earthquake Engineering Integrating Science, Engineering \& Policy, Los Angeles, CA, USA, 25-29 June 2018; Volume 3, pp. 1871-1881.

28. Pizzi, A.; Di Domenica, A.; Gallovič, F.; Luzi, L.; Puglia, R. Fault Segmentation as Constraint to the Occurrence of the Main Shocks of the 2016 Central Italy Seismic Sequence. Tectonics 2017, 36, 2370-2387. [CrossRef]

29. Ribilotta, E.; Giordano, E.; Ferrante, A.; Clementi, F.; Lenci, S. Tracking Modal Parameter Evolution of Different Cultural Heritage Structure Damaged by Central Italy Earthquake of 2016. Key Eng. Mater. 2019, 817, 334-341. [CrossRef]

30. Clementi, F.; Gazzani, V.; Poiani, M.; Lenci, S. Assessment of seismic behaviour of heritage masonry buildings using numerical modelling. J. Build. Eng. 2016, 8, 29-47. [CrossRef]

31. Rots, J.G. Smeared and discrete representations of localized fracture. Int. J. Fract. 1991, 51, 45-59. [CrossRef]

32. Lourenço, P.B. Recent advances in masonry modelling: Micromodelling and homogenisation. In Multiscale Modeling in Solid Mechanics: Computational Approaches; Imperial College Press: London, UK, 2009; pp. 251-294.

33. Da Porto, F.; Guidi, G.; Garbin, E.; Modena, C. In-Plane Behavior of Clay Masonry Walls: Experimental Testing and Finite-Element Modeling. J. Struct. Eng. 2010, 136, 1379-1392. [CrossRef] 